\title{
The biological basis of smoltification in Atlantic salmon
}

\author{
Francisco J. Morera ${ }^{a^{*},}$ Marcos Castro-Guarda ${ }^{a}$, Daniela Nualart ${ }^{b}$, Gabriel Espinosa ${ }^{a}$, \\ Jose L. Muñoz ${ }^{\mathrm{c}}$, Luis Vargas-Chacoff ${ }^{\mathrm{b}, \mathrm{d}}$
}

\begin{abstract}
Chile is the second-largest producer of Atlantic salmon in the world, and the Chilean salmon production accounts for $27 \%$ of the world's production. One important step of the productive cycle in freshwater is the smoltification process that prepares the fish for the marine life stage. This review describes the biological basis of smoltification in Atlantic salmon, with particular attention on branchial osmoregulatory adaptations. We also discuss some of the infectious diseases and problems in smoltification (two of the main causes of losses in Chilean aquaculture) that could be related from a physiological point of view.

Key words: Chilean salmon culture, smoltification, Atlantic salmon.
\end{abstract}

\section{GENERAL BACKGROUND}

Aquaculture provides the world's growing population with both food and livelihoods (FAO 2020). Currently, aquaculture is the fastest-growing sector in the animal production industry worldwide, with an annual increase of $7.5 \%$ since 1970 (FAO 2020). According to the Food and Agriculture Organization (FAO) of the United Nations, aquaculture's contribution to total fish production has risen steadily in all continents, and Chile is one of the top-ten aquaculture producers. These ten countries contributed to $88 \%$ of the entire world's production by mass. Moreover, China is the major producer country by far (FAO 2020). In 2019, the value of seafood exported by China was more than USD 20 billion while Chile exported about USD 5 billion of seafood in the same year ${ }^{1}$.

Chilean aquaculture production relies heavily on salmonids farming (salmon and trout), accounting for $84 \%$ of total Chilean aquaculture production and practically $100 \%$ of all farmed fish. According to Subpesca-Chile, in 2019 Atlantic salmon (Salmo salar) was the main species farmed in Chile, accounting for $58.7 \%$ of total production, followed by Pacific salmon (Oncorhynchus kisutch) with $36.2 \%$, and Rainbow trout (Oncorhynchus mykiss) with $5.1 \%$ (Subpesca Chile 2020).

Received: 20.07.2020.

Accepted: 15.12 .2020 .

${ }^{a}$ Laboratorio de Bioquímica Aplicada, Instituto de Farmacología y Morfofisiología, Facultad de Ciencias Veterinarias, Universidad Austral de Chile, Valdivia, Chile.

bLaboratorio de Fisiología de Peces, Instituto de Ciencias Marinas y Limnológicas, Universidad Austral de Chile, Valdivia, Chile.

${ }^{c}$ Centro de Investigación y Desarrollo i Mar, Universidad de los Lagos, Puerto Montt, Chile.

${ }^{\mathrm{d} C e n t r o ~ d e ~ A l t a s ~ L a t i t u d e s, ~ F o n d a p-I D E A L, ~ U n i v e r s i d a d ~ A u s t r a l ~ d e ~}$ Chile, Valdivia, Chile.

*Corresponding author: FJ Morera, fjmorera@uach.cl

1 https://thefishsite.com/articles/rabo
Chile is the second-largest producer of Atlantic salmon in the world, with an annual average volume close to 800,000 tons between $2014^{2}$ and $2019^{3}$. Chilean production of salmon species amounts for $27 \%$ of the world's production, while Norway continues to lead with $52 \%$ of the share (Iversen et al 2020). However, after the massive ISA virus infection in 2007, the Chilean government and the salmon industry put significant efforts into basic and applied research on many of the key aspects of salmon production to maintain Chile in a leading position worldwide (Olson and Criddle 2008, Martini Costa 2019, Iversen et al 2020).

\section{SUMMARY OF THE SALMON AQUACULTURE PROCESS}

In the last 40 years, the global salmon farming industry has switched from a small-scale operation to a mass-production scheme (Bjørndal and Aarland 1999, McLeod et al 2006, Olson and Criddle 2008). The high level of industrialisation of salmon aquaculture is significant due to the incremental success of strategies to adapt the salmon wildlife cycle to a large-scale farming setting.

Wild salmonids begin their life in freshwater. Adult salmons spawn in freshwater, their eggs hatch into alevins, and then they begin their development into fry and parr. At this stage, environmental cues initiate the smoltification process, preparing the fish for downstream migration and entrance into seawater, where they will grow up as a marine, predatory species (Björnsson and Bradley 2007, Björnsson et al 2011). This anadromous strategy confers reproductive and developmental advantages to salmon because it enables them to utilise a relatively safe environment provided by freshwater for reproduction, whereas juvenile migration towards the ocean allows

\footnotetext{
https://www.salmonchile.cl/en/production/

3 https://www.salmonexpert.cl/article/industria-salmonicultora-seacerca-al-milln-de-toneladas-de-produccin-anual/
} 


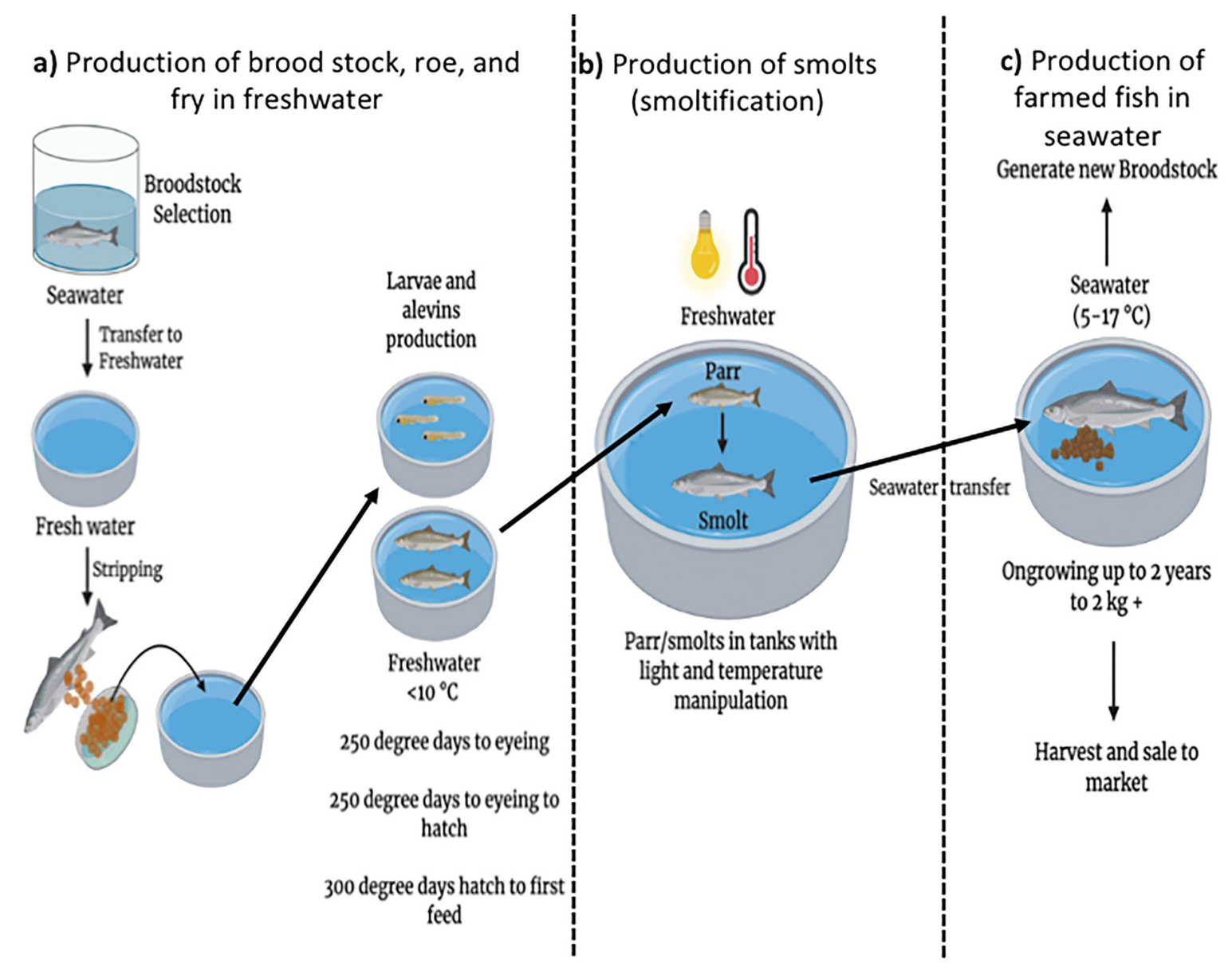

Figure 1. Summary of the salmon production process.

them to feed on a rich supply of fish and other marine organisms (Stefansson et al 2008). Thus, smoltification represents the key turning point in the anadromous life cycle of Atlantic salmon (McCormick 2009, Björnsson et al 2011).

The salmon production process was developed considering the biological background of this typically anadromous life cycle. The salmon production process can be divided into three steps (see figure 1): a) production of broodstock, roe, and fry in freshwater; b) production of smolts (smoltification) in freshwater; and c) growing farmed fish in seawater (Asheim et al 2011, Asche and Bjorndal 2011).

The production cycle of farmed salmon takes about three years on average. During the first year of production, the eggs are fertilised and the fish develop and grow to approximately 100 grams in a controlled freshwater environment (figure 1a and 1b) (Bergheim et al 2009). Subsequently, fish are transferred to seawater cages, where they continue growing until approximately $4-5 \mathrm{~kg}$ for 14-24 months (figure 1c). After reaching harvesting size, fish are transported to primary processing plants where they are slaughtered and gutted (Mowi 2020).

\section{SMOLTIFICATION IN THE SALMON PRODUCTION CYCLE}

In the productive salmon chain, the industrial smoltification phase (figure 1b) correlates directly with production efficiency because smolt quality impacts the indicator "yield per smolt" (harvest weight per smolt released). "Yield per smolt" is calculated as the fraction between harvest weight for each smolt transferred to seawater. This parameter is influenced by premature mortality rates, disease, temperature and growth attributes. The Faroe Islands reached a higher yield per smolt in the world: $4.87 \mathrm{~kg}$ in 2013. In Norway, the average yield per smolt was estimated at $3.71 \mathrm{~kg}$, and in Chile, it was $3.58 \mathrm{~kg}$ in the same year.

The average yield per smolt for the Chilean salmon industry in 2013 was estimated at only $3.58 \mathrm{~kg}$ (Mowi 2020), and during 2015 it reached a minimum value of only $3.0 \mathrm{~kg}$. After improving the production strategy, productivity reached a record level of over $4.4-4.5 \mathrm{~kg}$ per smolt during 2018, according to Aquabech ${ }^{4}$.

\footnotetext{
4 https://www.fishfarmingexpert.com/article/chile-production-hasreached-record-levels/
} 
In the yearling production system, smoltification occurs following the seasonal yearling signals (natural photoperiod and temperature) rather than being dictated by the regular artificial programming of salmon. To start the smoltification, the salmon must reach a size-related threshold to respond to the ambiental signals. During the yearling smoltification, temperatures are not expected to be a problem since ambiental water supply is used following the species' natural smoltification period.

In the under-yearling production system, smoltification must be induced artificially through photomanipulation as the most common strategy, and the process takes place at a time of the year that is different to that dictated by regular biological, but artificially induced, programming. In this system, smoltification is induced by an artificial "winter signal" (alternating light and dark cycles of 12 hours), typically during late summer, when ambient temperatures are at their highest. In a typical photomanipulation program, the recommendation is to avoid a temperature drop during the transition from the first to the second period (Staurnes et al 2001).

\section{BIOLOGICAL BASIS OF PHYSIOLOGICAL CHANGES THAT OCCUR DURING SMOLTIFICATION}

In nature, smoltification, also called parr-smolt transformation, is a complex adaptation process driven by the endocrine system that consists of several independent but coordinated developmental changes in the biochemistry, physiology, morphology, and behaviour of juvenile salmon (McCormick 2013). These changes possess a high energetic cost for the fish and correlate with decreased defenses related to the immune system (Pontigo et al 2016): however, this process prepares the fish for downstream migration and transition to the marine life stage (Björnsson and Bradley 2007, Stefansson et al 2008). Important components of the parr-smolt transformation are i) environmental cues, primarily photoperiod and temperature (Björnsson and Bradley 2007); ii) endocrine control of smoltification (Björnsson et al 2011), and iii) physiological changes in osmoregulation that allow the smolt to thrive in high-salt environments (Clarke et al 1996, McCormick 2013).

\section{ENVIRONMENTAL REGULATION OF SMOLTIFICATION}

Photoperiod and seasonal temperature fluctuations are two important environmental cues that work together to transform Atlantic salmon parrs into smolts (Clarke et al 1996). In the Northern hemisphere, smoltification in wild salmon is complete by spring, when a rising temperature of $8-10{ }^{\circ} \mathrm{C}$ initiates wild smolt migration to seawater (Jonsson and Ruud-Hansen 1985, Clarke et al 1996). The mechanism by which photoperiodic information is translated into a neuroendocrine response in teleosts has not been fully elucidated. Different preparatory photoperiods show differential gill NKA activity and expression patterns in ionocytes (van Rijn et al 2020). Melatonin secretion by the pineal gland of salmonids can be directly stimulated by photoperiod (Falcón et al 2007). Also, elevated temperature increases melatonin secretion, and the salmon pineal gland could be working as a photoperiod and temperature sensor (Nisembaum et al 2020).

\section{HORMONAL REGULATION OF SMOLTIFICATION}

Parr-smolt transformation engages several endocrine signaling systems (see figure 2) (Björnsson et al 2011). After salmons have reached a size- or growth-related threshold, the light-brain-pituitary axis is stimulated by photoperiod and seasonal temperature, resulting in simultaneous increments of growth hormone $(\mathrm{GH})$, cortisol, and thyroid hormones (McCormick 2001). Besides its growth related functions, GH modulates intermediary metabolism and osmoregulatory mechanisms in fish by stimulating somatomedin activity, such as insulin-like growth factors IGF-1 and IGF-2 (McCormick et al 1991, Madsen et al 1995, McCormick 1996). GH and cortisol interact to control hyperosmoregulatory mechanisms in gills, gut, and kidneys, promoting increased salinity tolerance and changes in growth (weight to length ratio) and intermediary metabolism. In gills, cortisol and the GH/ IGF-1 axis promote differentiation of salt-secreting ionocytes (see next section for details), a process that requires upregulation of three major osmoregulatory membrane transporters: the sodium-potassium ATPase (NKA), the sodium-potassium-2 chloride cotransporter 1 (NKCC1), and the cystic fibrosis transmembrane conductance regulator (CFTR) (Hwang et al 2011).

Lastly, thyroid hormones regulate olfactory imprinting, metabolism, morphological changes such as silvering, and possibly behaviour (McCormick 2013), whereas prolactin in smoltification is thought to be a general inhibitor of most aspects of smolt development (Sakamoto and McCormick 2006). An increase in thyroid hormones (plasma T4) is detected in hatchery smolt after release and in wild smolt during migration (Iwata et al 2003, McCormick et al 2003). Also, plasma T4 increases after smolts are exposed to water with different chemical compositions (Hoffnagle and Fivizzani 1990) or during entry into estuarine environments (McCormick et al 2013).

\section{OSMOREGULATORY CHANGES IN GILLS DURING SMOLTIFICATION}

As mentioned above, salmonids begin their life cycle in freshwater, where they are hyperosmotic to the external medium. Osmotic pressure favours water entry into the body and the loss of salt by diffusion across the gill. To compensate for this passive flow of water and ions to maintain homeostasis, the fish eliminates excess water as diluted urine and obtains salts from food in the intestine 


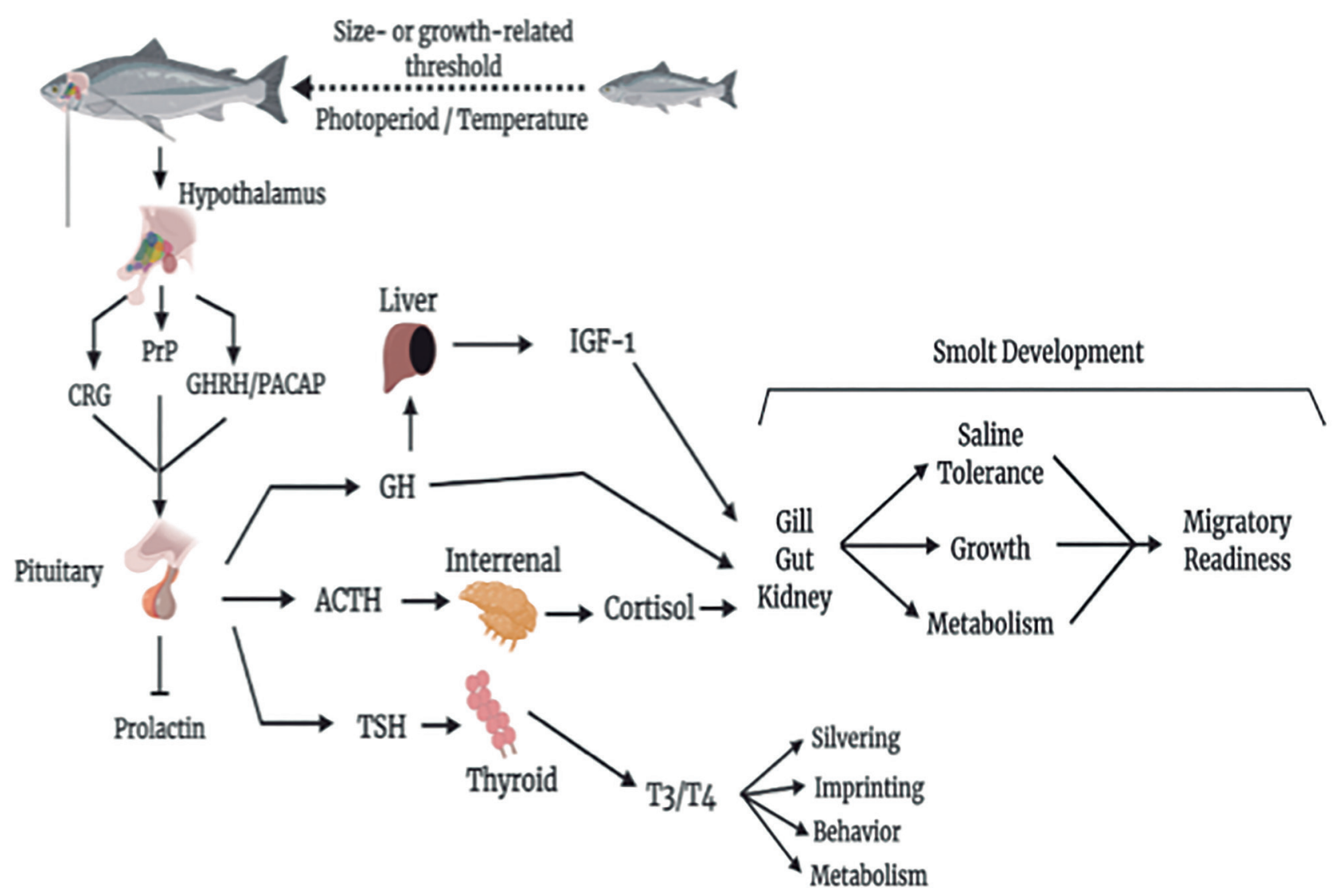

Figure 2. Neuroendocrine control of smoltification (modified from McCormick 2013). Increased response of the light-brain-pituitary axis stimulates circulating levels of growth hormone $(\mathrm{GH})$, cortisol, and thyroid hormones. This response is triggered when the fish reach a size- or growth-related threshold to initiate smoltification in response to photoperiod/temperature stimuli. GH and cortisol interact to control hyperosmoregulatory mechanisms in the gill, gut, and kidney, resulting in increased salinity tolerance, as well as changes in growth and metabolism. CRF: corticotropin-releasing factor; PrP: prolactin-releasing peptide; GHRH: growth hormone-releasing hormone; PACAP: pituitary adenylate cyclase-activating peptide; ACTH: adrenocorticotropic hormone; TSH: thyroid-stimulating hormone.

and water by active uptake through the gill's epithelium. As they move into seawater, the osmotic gradient is reversed because the internal fluids of salmonids are approximately one-third the osmolarity of seawater, and they become hypoosmotic relative to the external medium. Accordingly, salmons lose water and gain salts by passive diffusion. As compensatory mechanisms, they drink seawater, reduce their urine production, and actively secrete salts across the gill's epithelium through specialised cells called ionocytes, mitochondria-rich (MR) cells, or chloride cells (Clarke et al 1996).

One of the key events in osmoregulatory changes during the parr-smolt transformation involves fine-tuning of the ion-transporting machinery in the gill epithelia (Tipsmark et al 2008). Ion transport is primarily carried out by MR cells (Madsen et al 2015) and requires expression changes in NKA (D'Cotta et al 2000), NKCC1, and other critical proteins at the cell surface, such as CFTR and claudins (Hirose et al 2003, Hiroi et al 2005). In most euryhaline teleosts, upregulation of gill NKA (Kamiya and Utida 1969, Morgan et al 1997, Seidelin et al 2000) and NKCC1
(Pelis et al 2001, Tipsmark et al 2002, Wu et al 2003) are associated with seawater acclimation.

$\mathrm{NaCl}$ secretion by teleost gills, necessary in seawater life, is accomplished via secondary active transport of $\mathrm{Cl}^{-}$ and passive transport of $\mathrm{Na}^{+}$(figure 3). The driving force for active transport is provided by NKA, which maintains intracellular $\mathrm{Na}^{+}$at low levels and intracellular $\mathrm{K}^{+}$at high levels, compared to the extracellular medium (Marshall and Grosell 2006). This $\mathrm{NaCl}$ secretion mechanism needs an additional condition to work in seawater: a thermodynamic requirement to recycle $\mathrm{K}^{+}$out via conductive pathways (potassium channels, figure 3 ). The molecule responsible for this $\mathrm{K}^{+}$transport is still unknown in salmonids, but several $\mathrm{K}^{+}$channels may be involved in the function of MR cells in other teleosts (Marshall and Grosell 2006). One plausible candidate is the inward-rectifying $\mathrm{K}^{+}$channel (eKir), highly expressed in gills of the seawater-acclimated Japanese eel (Suzuki et al 1999). Another candidate is a large-conductance, calcium-activated $\mathrm{K}^{+}$channel (called BK for "Big K "), whose expression was recently detected in gills from the teleost fish Porichthys notatus (Rohmann 


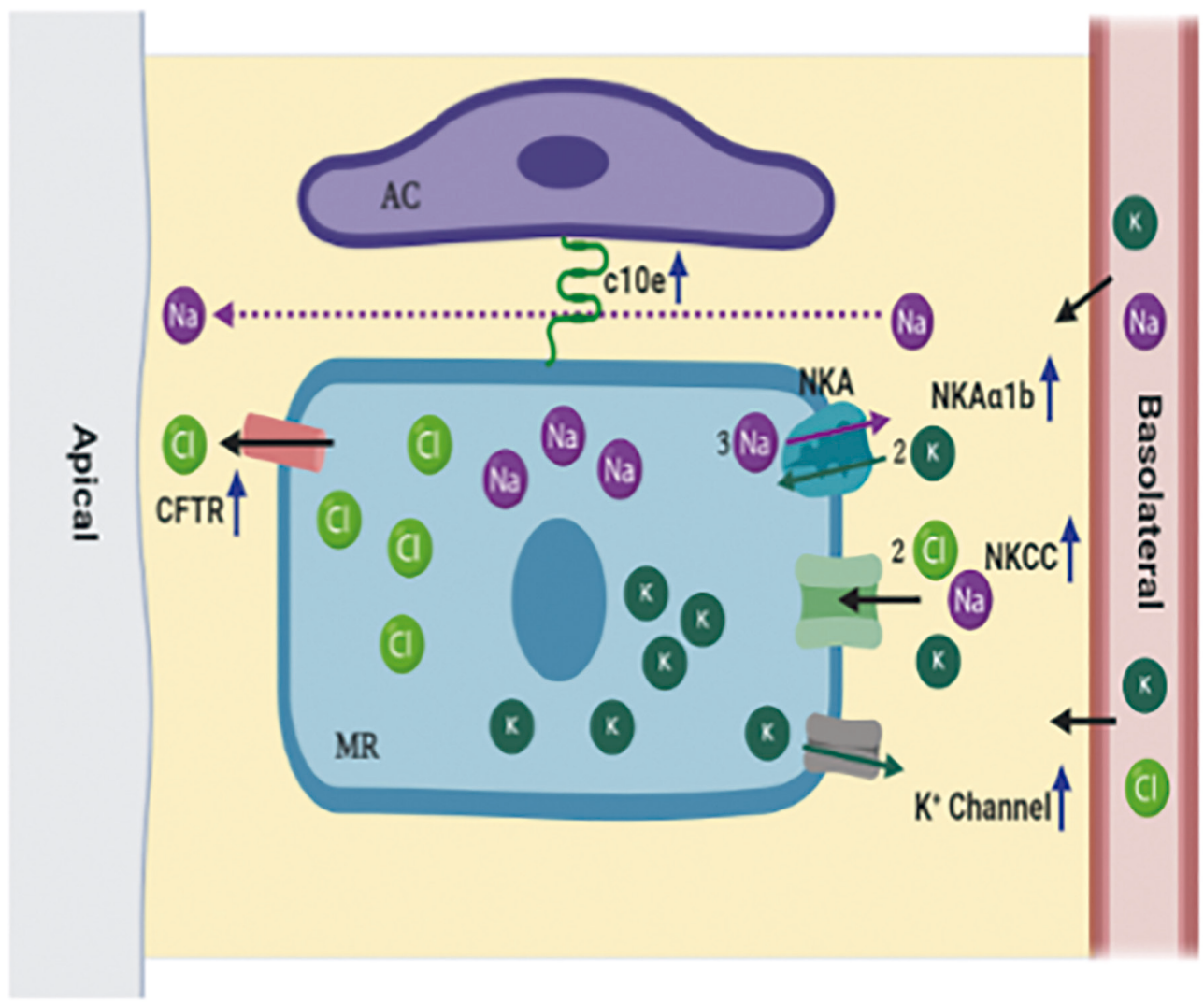

Figure 3. Model of $\mathrm{NaCl}$ secretion in the gill epithelium after seawater acclimation (Modified from Marshall and Grosell, 2006). A leaky paracellular shunt is formed (Claudin 10e mediated) between MR and AC that allows Na+ to be passively secreted. In MR cells $\mathrm{Cl}$ - enters via the $\mathrm{Na}+, \mathrm{K}+, 2 \mathrm{Cl}$ co-transporter (NKCC) driven by the $\mathrm{Na}+$ gradient, which is maintained by Na+, $\mathrm{K}+-\mathrm{ATPase}$ (NKA). $\mathrm{Cl}-$ accumulates above its electrochemical equilibrium intracellularly, and exits through the CFTR type anion channels at the apical membrane. The $\mathrm{K}+$ ion is also accumulated intracellularly until it exits through $\mathrm{K}+$ channels. During smolt development, the amount of NKAalb subunit increases. After exposure to SW, NKAa1b increases even more. NKCC, CFTR, and claudin 10e are also upregulated in FW during smolt development and increased further after exposure to SW.

NKA: Na+/K+-ATPase; NKCC: Na+/K+/Cl- cotransporter; CFTR: cystic fibrosis transmembrane regulator; MR: mitochondria-rich cell; AC: accessory cell.

et al 2009). Also, an inward-rectifying $\mathrm{K}^{+}$channel (Kir1.1 or ROMK for Renal Outer Medullary $\mathrm{K}^{+}$channel) and a BK channel were detected in MR cells from Mozambique tilapia (Furukawa et al 2012) and, more recently, in the gills from rainbow trout and Atlantic salmon by our research team (Loncoman et al 2015).

The capacity to measure the activity or the expression of different molecular components of this salt secretion machinery has provided useful tools for examining smolt development, and it will be discussed with greater detail in the next section.

\section{MARKERS OF SMOLTIFICATION}

Historically, research on smoltification has focused on understanding smolt development in the aquaculture industry and, in particular, the need to control the timing and quality of smolt for the transfer of juveniles from freshwater into ocean net pens (McCormick 2013). Knowing exactly when the smolts are ready to be relocated to seawater is crucial for the productivity of salmon farmers. Increased tolerance to salinity is often measured by either increased survival or by lower plasma electrolytes and osmolality after direct transfer from freshwater to high salinity (a "seawater challenge" as an example of a salinity tolerance test) (Clarke et al 1996, McCormick 2013). The main disadvantage of salinity tolerance tests is that they fail to distinguish between seawater tolerance and transient adaptation: since some fish may show increased survival but ultimately fail to adapt to long-term seawater exposure (Iremonger 2008).

Currently, the use of molecular markers of smoltification (see table 1) are used to accurately determine the transfer time to seawater since many physiological 
Table 1. Common laboratory methods to test smoltification.

\begin{tabular}{|c|c|c|c|}
\hline Name & Technique & Assay & References \\
\hline Gill NKA activity & Spectrophotometry & $\begin{array}{l}\text { Coupled assay to quantify ADP generated } \\
\text { by ATPase activity by detecting the disap- } \\
\text { pearance of NADH at } 360 \mathrm{~nm}\end{array}$ & (McCormick 1993) \\
\hline Gill NKA activity & Spectrophotometry & $\begin{array}{l}\text { Detection of Pi generated by ATPase activity } \\
\text { at } 312 \mathrm{~nm}^{1} \text { or } 578 \mathrm{~nm}^{2}\end{array}$ & $\begin{array}{l}y^{1}(\text { Zaugg } 1982) \\
{ }^{2}(\text { Flik } \text { et al } 1983)\end{array}$ \\
\hline $\begin{array}{l}\text { NKA subunit mRNA } \\
\text { expression }\end{array}$ & Real-Time PCR & $\begin{array}{l}\text { PCR primers for specific detection of } \\
\text { mRNA from NKA subunits ala and alb }\end{array}$ & (McCormick et al 2009) \\
\hline NKA protein expression & Immunohistochemistry & Antibodies against the NKA protein & (McCormick et al 2013) \\
\hline
\end{tabular}

changes produced during the parr-smolt transformation are detrimental to continued life in freshwater, and they tend to revert relatively fast if the fish are not able to enter seawater environments before smoltification is complete (the "smolt window") (Stefansson et al 2008). In most instances, the salmon industry uses a single enzymatic marker for smoltification: the enzymatic activity of gill NKA, which activity increases during the transition from parr to smolt (McCormick et al 2013, Zaugg 1982, McCormick et al 2009, Nilsen et al 2007). This protein activity is often considered an indicator of smolt development (McCormick 1993, Clarke et al 1996). The Chilean salmon industry uses NKA enzymatic activity in gills as a main marker to determine the timing of smolt transfer to seawater.

Many scientific publications describe that some of the salt secretion machinery`s critical molecules expressed in the gills of salmonids correlate with seawater adaptation. Atlantic salmon expresses two major NKA $\alpha$ isoforms in distinct gill ionocytes. NKA $\alpha 1 \mathrm{a}$ is the most abundant isoform in freshwater, whereas NKA $\alpha 1 b$ predominates in seawater (McCormick et al 2009). Gill mRNA levels of NKA $\alpha 1 \mathrm{~b}$ increase during Atlantic salmon smolting, whereas NKA $\alpha 1$ a mRNA decreases (Nilsen et al 2007). Also, co-transporters (NKCC1), aquaporins, and ion channels (CFTR, ROMK, and BK) are expressed in gills covary with salinity adaptation (Tipsmark et al 2010, Furukawa et al 2012; McCormick 2013, Loncoman et al 2018). Tipsmark et al (2008) showed that Claudin10e mRNA levels, a family of membrane proteins that form tight junctions and thus determine transepithelial resistance and ion permeability, also increase during smolt development and after exposure to seawater. All these molecules are considered potential molecular markers of smoltification, but there is no available evidence to determine its true predictive value in decreasing fish mortality in seawater. Some of these alternative markers are being implemented in Chile for research purposes (Loncoman et al 2015, Loncoman et al 2018, Vargas-Lagos et al 2018), except for the NKA subunits that some laboratories in Norway and Chile measure as a service (see table 1); but the salmon industry has not adopted these markers for routine tests, probably due to the lack of quantitative data about any advantage over NKA measurements alone.

The search for new possible markers for smoltification is ongoing using all available techniques, even high throughput analyses such as transcriptomics (Houde et al 2020, Versen et al 2020, West et al 2020) and small RNA sequencing (Shwe et al 2020).

\section{SMOLT-WINDOW OR SMOLTIFICATION WINDOW}

In industrial salmon production, survival and growth performance in seawater are the two major manifestations of smoltification. However, if smolts are prevented from reaching seawater exposure, several of the preparatory changes associated with marine life are reverted, a process known as desmoltification in Atlantic salmon or parr-reversion in Pacific salmonids (figure 4) (Hoar 1988, Duston et al 1991, Stefansson et al 1998). This natural reverting process closes the "smolt-window" during which smolts can enter and quickly adapt to seawater. Conceptually, the smolt-window (or smoltification window) is considered the period when physiological conditions to be transferred into seawater are at their optimal peak (Sharron 2015). The smolt-window is operationally associated only with the increase in gill NKA enzyme activity (figure 4).

The smolt window duration is in the range of 300-400 degree-days $\left(\mathrm{d}^{\circ} \mathrm{C}\right)$ (Stefansson et al 1998, McCormick et al 1999, Stefansson et al 2008). In the salmon farming industry, the decision to transfer smolt into seawater is taken using a threshold value of NKA activity, without any consideration of its dynamic properties, i.e. whether NKA activity is on the rise (smoltification phase), reaching its peak, or in decline (desmoltification phase). Zydlewski and Zydlewski (2012) show that gill NKA activity measurements are predictive of performance during the first few days of acclimation but, after transfer, fish grew at the same rate, with no differences in fish size and growth rate, among groups with initially different gill NKA activities. They concluded that gill NKA expression in freshwater at the peak of smolting 


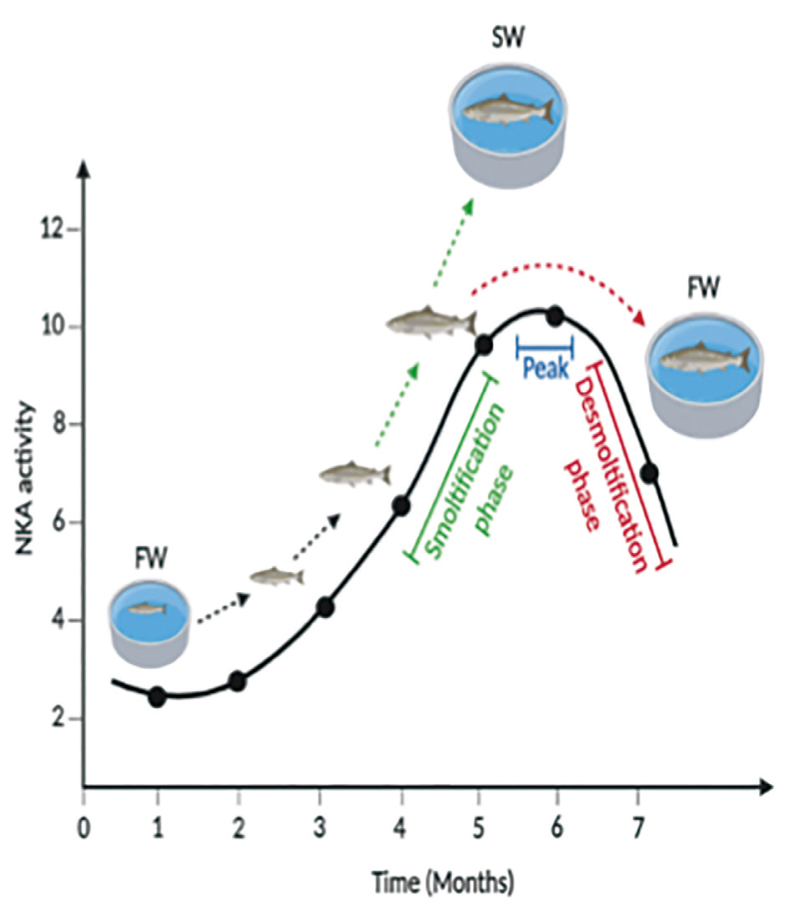

Figure 4. Changes in gill NKA activity levels during the smolt development of Atlantic salmon (according to McCormick 2013).

does not predict long-term growth in seawater (Zydlewski and Zydlewski 2012).

\section{CURRENT CHALLENGES IN CHILEAN SALMON PRODUCTION: ARE SMOLTIFICATION AND INFECTIOUS DISEASES RELATED?}

Aquaculture farming in Chile has experienced a highspeed growth, mainly due to favourable geographical and environmental conditions, but this fast growth, together with confinement systems and the presence of native life, increases the risk of infectious disease outbreaks. The 2019 annual reports from SERNAPESCA (SERNAPESCA 2019) describes the principal causes of mortality in the Chilean salmon aquaculture. This report pointed out that two of the leading causes are "unadapted" fish (fish with problems in osmoregulation by deficient smoltification, $11.2 \%$ ) and infectious diseases (23.9\%).

Historically, smoltification problems are the other leading cause of economic losses in Chilean salmon aquaculture because the amount of "delayers and unadapted" fish at the seawater stage is still significant, with an $11.2 \%$ in 2019 , being the first one the infectious diseases $(23.9 \%)$ as we previously mentioned (SERNAPESCA 2019). These groups consist of fish seeded in seawater during a suboptimal developmental phase of smoltification that prevents adaptation to their new environment. The "unadapted" are fish that do not adapt to the marine environment early on and die after entering the sea, mainly due to osmoregulatory problems. The "delayers" are fish that adapted relatively well after entering the sea but subsequently present impaired growth and productive performance . $^{5}$

In recent years, some Chilean smoltification facilities have adopted the Norwegian production standards from their company owners, and they claim that the problems regarding smoltification have been solved.

It is particularly surprising that despite the research focused on smoltification, very little has been studied regarding the impact of this transformation on the salmon`s immune system. Several earlier studies in smolts and post-smolts of Atlantic salmon produced evidence for a possibly weakened immunity. Decreased plasma lysozyme, IgM levels, and leucocyte levels were observed (Muona and Soivio 1992, Melingen et al 1995). In the last years, some groups have started to show some data of association between the increase in infectious diseases that occurs after transfer to seawater with an alteration in the immune response during smoltification. Post-smolts show a weak response against viral (Moore et al. 2017; Nuñez-Ortiz et al. 2018; Jensen et al. 2019) and also, their skin barrier to infection (Karlsen et al. 2018) or gut immune functions (Wang et al. 2020) are weak during the first post-smolt period.

Recent transcriptomics analysis have demonstrated repressed expression of genes associated with the immune system during smoltification and after seawater transfer (Johansson et al 2016, Krasnov et al 2016); opening the possibility of a biological relationship between two of the most important causes of death in Chilean aquaculture (infectious diseases and problems in smoltification) and a warning about the need for more scientific research regarding this relationship between two different and disconnected fields of study.

\section{FUTURE PERSPECTIVES}

Smoltification in salmonids continues to be a field of study in constant progress: new transporters are being discovered that change their expression during this process (Fleming et al 2019, Koltenyuk et al 2020, McKay et al 2020), and the parr-smolt transformation process is characterised in new strains of salmon in culture (van Rijn et al 2020), or wild salmon (Bernard et al 2019). Even different aspects of the process are evaluated (Nemova et al 2020), and the biological character of the process continues in development (Striberny et al 2021).

\section{ACKNOWLEDGEMENTS}

This work was supported by the grants: FONDECYT REGULAR 1180957 (to F.J.M., J.L.M. and L.V.C.); DID-UACH S-2016-22 (to F.J.M. and L.V.C.); FONDECYT REGULAR 1190857 (to J.L.M.,

5 https://www.salmonexpert.cl/article/pathovet-da-un-paso-en-laprediccin-de-peces-desadaptados-y-rezagados/ 
L.V.C. and F.J.M.) and FONDAP IDEAL 15150003 (to L.V.C.). The authors would also like to acknowledge Vicerrectoría de Investigación, Desarrollo y Creación Artística of Universidad Austral de Chile for their constant support.

\section{REFERENCES}

Asche F, Bjorndal T. 2011. The economics of salmon aquaculture. Wiley-Blackwell, Oxford, UK.

Asheim LJ, Dahl RE, Kumbhakar SC, Oglend A, Tveteras R. 2011. Are prices or biology driving the short-term supply of farmed salmon? Mar Resour Econ 26, 343-357.

Bergheim A, Drengstig A, Ulgenes Y, Fivelstad S. 2009. Production of Atlantic salmon smolts in Europe - current characteristics and future trends. Aquacult Eng 41, 46-52.

Bernard B, Mandiki R, Duchatel V, Rollin X, Kestemont P. 2019. A temperature shift on the migratory route similarly impairs hypo-osmoregulatory capacities in two strains of Atlantic salmon (Salmo salar L.) smolts. Fish Physiol Biochem 45, 1245-1260.

Bjørndal T, Aarland K. 1999. Salmon aquaculture in Chile. Aquacult Econ Manag 3, 238-253.

Björnsson BT, Bradley TM. 2007. Epilogue: past successes, present misconceptions and future milestones in salmon smoltification research. Aquaculture 273, 384-391.

Björnsson BT, Stefansson SO, McCormick SD. 2011. Environmental endocrinology of salmon smoltification. Gen Comp Endocr 170, 290-298.

Clarke WC, Saunders RL, McCormick SD. 1996. Smolt production. In: Pennel W, Barton BA (eds). Principles of salmonid culture. CRC Press, Elsevier, Amsterdam, The Netherlands, Pp 517-567.

D'Cotta H, Valotaire C, Le Gac F, Prunet P. 2000. Synthesis of gill Na+$\mathrm{K}+$-ATPase in Atlantic salmon smolts: differences in alfa-MRNA and alfa-protein levels. Am J Physiol-Reg I 278, R101-R110.

Duston J, Saunders RL, Knox DE. 1991. Effects of increases in freshwater temperature on loss of smolt characteristics in Atlantic salmon (Salmo salar). Can J Fish Aquat Sci 48, 164-169.

Falcón J, Besseau L, Sauzet S, Boeuf G. 2007. Melatonin effects on the hypothalamo-pituitary axis in fish. Trends Endocrin Met 18, 81-88.

Fleming MS, Maugars G, Lafont A, Rancon J, Fontaine R, et al. 2019. Functional divergence of thyrotropin beta-subunit paralogs gives new insights into Salmon smoltification metamorphosis. Sci Rep-UK 9, 4561.

Flik G, Wendelaar Bonga SE, Fenwick JC. 1983. Ca2+-dependent phosphatase and ATPase activities in eel gill plasma membranes. I. Identification of $\mathrm{Ca} 2+-$ activated ATPase activities with non-specific phosphatase activities. Comp Biochem Physiol B 76B, 745-754.

Furukawa F, Watanabe S, Kimura S, Kaneko T. 2012. Potassium excretion through ROMK potassium channel expressed in gill mitochondrion-rich cells of Mozambique tilapia. Am J Physiol-Reg I 302, R568-R576.

Hiroi J, McCormick SD, Kaneko RO, Kaneko T. 2005. Functional classification of mitochondrion-rich cells in euryhaline mozambique tilapia (Oreochromis mossambicus) embryos, by means of triple immunofluorescence staining for $\mathrm{Na}+\mathrm{K}+$-ATPase, $\mathrm{Na}+\mathrm{K}+/ 2 \mathrm{Cl}-$ cotransporter and CFTR anion channel. J Exp Biol 208, 2023-2036.

Hirose S, Kaneko T, Naito N, Takei Y. 2003. Molecular biology of major components of chloride cells. Comp Biochem Phys B 136, 593-620.

Hoar WS. 1988. The physiology of smolting salmonids. In: Fish Physiology. Vol. XIB. Hoar WS, Randall DJ (eds). Academic Press Inc, London, UK, Pp 275-343.

Hoffnagle TL, Fivizzani AJ. 1990. Stimulation of plasma thyroxine levels by novel water chemistry during smoltification in chinook salmon (Oncorhynchus tshawytscha). Can J Fish Aquat Sci 47, 1513-1517.

Houde ALS, Günther OP, Strohm J, Ming TJ, Li S, et al. 2020. Discovery and validation of candidate smoltification gene expression biomarkers across multiple species and ecotypes of Pacific salmonids. Conserv Physiol 7, coz051.
Hwang P, Lee T, Lin L. 2011. Ion regulation in fish gills: recent progress in the cellular and molecular mechanisms. Am J Physiol-Reg I 301, R28-R47.

Iremonger GS. 2008. Smoltification and growth retardation in New Zealand King salmon Oncorhynchus tshawytscha (Walbaum). Master Thesis, University of Canterbury, Canterbury, New Zealand.

Iversen A, Asche F, Hermansen Ø, Nystøyl R. 2020. Production cost and competitiveness in major salmon farming countries 2003-2018. Aquaculture 522, 735089.

Iwata M, Tsuboi H, Yamashita T, Amemiya A, Yamada H, et al. 2003. Function and trigger of thyroxine surge in migrating chum salmon Oncorhynchus keta fry. Aquaculture 222, 315-329.

Jensen I, Overrein M, Fredriksen BN, Strandskog G, Seternes T. 2019. Differences in smolt status affect the resistance of Atlantic salmon (Salmo salar L.) against infectious pancreatic necrosis, while vaccine-mediated protection is unaffected. J Fish Dis 42, 1271-1282.

Johansen L, Dahle MK, Wessel Ø, Timmerhaus G, Løvoll M, et al. 2016. Differences in gene expression in Atlantic salmon Parr and smolt after challenge with Piscine othoreovirus (PRV). Mol Immunol $73,138-150$.

Johansson LH, Timmerhaus G, Afanasyev S, Jorgensen SM, Krasnov A. 2016. Smoltification and seawater transfer of Atlantic salmon (Salmo salar L.) is associated with systemic repression of the immune transcriptome. Fish Shellfish Immun 58, 33-41.

Jonsson B, Ruud-Hansen J. 1985. Water temperature as the primary influence on timing of seaward migrations of Atlantic salmon (Salmo salar) smolts. Can J Fish Aquat Sci 42, 593-595.

Kamiya M, Utida S. 1969. Sodium-potassium-activated adenosinetriphosphatase activity in gills of fresh-water, marine and euryhaline teleosts. Comp Biochem Physiol 31, 671-674.

Karlsen C, Ytteborg E, Timmerhaus G, Høst V, Handeland S, et al. 2018. Atlantic salmon skin barrier functions gradually enhance after seawater transfer. Sci Rep-UK 8, 9510.

Koltenyuk V, Nelson N, McKay I, Lema S, McCormick S, et al. 2020. Diminished expression of $\mathrm{Na}+\mathrm{HCO} 3$ - cotransporter 1.2a (Nbce1.2a) MRNA accompanies seawater acclimation in Atlantic salmon. The FASEB Journal 34, 1

Krasnov A, Afanasyev S, Baranski M, Dahle M, Johansson L, et al. 2016. Smoltification and breeding for rapid growth may suppress immunity of Atlantic salmon: evidence from transcriptome analyses. Fish Shellfish Immunol 53, 79.

Loncoman CA, Gutiérrez L, Strobel P, Alarcón P, Contreras C, et al. 2015. Application of a real-time PCR assay to detect BK potassium channel expression in samples from Atlantic salmon (Salmo salar) and rainbow trout (Oncorhynchus mykiss) acclimated to freshwater. Arch Med Vet 47, 215-220.

Loncoman CA, Saravia J, Gutierrez L, Contreras C, Oyarzún R, et al. 2018. BK potassium channel MRNA level changes in gills of Atlantic salmon after brackish water transfer. Aquaculture 491, 184-189.

Madsen SS, Engelund MB, Cutler CP. 2015. Water transport and functional dynamics of aquaporins in osmoregulatory organs of fishes. Bioll Bull 229, 70-92.

Madsen SS, Jensen MK, Nhr J, Kristiansen K. 1995. Expression of $\mathrm{Na}(+)-\mathrm{K}(+)-A T P a s e$ in the brown trout, Salmo trutta: In vivo modulation by hormones and seawater. AM J Physiol Regul Integr Comp Physiol 269, R1339-R1345.

Marshall WS, Grosell M. 2006. Ion Osmoregulation , and Acid-Base Balance. In: The Physiology of Fishes. In: Evans DH, Claiborne JB (eds). $3^{\text {rd }}$ ed. Taylor \& Francis, Abingdon, UK, Pp 177-230.

Martini Costa JA. 2019. Chilean blue revolution: the rise of salmon aquaculture and the state. MA Thesis, Memorial University of Newfoundland, St. John's, Canada.

McCormick SD, Sakamoto T, Hasegawa S, Hirano T. 1991. Osmoregulatory actions of insulin-like growth factor-I in rainbow trout (Oncorhynchus mykiss). J Endocrinol 130, 87-92.

McCormick SD. 1993. Methods for nonlethal gill biopsy and measurement of $\mathrm{Na}+, \mathrm{K}+$-ATPase Activity. Can J Fish Aquat Sci 50, 656-658. 
McCormick SD. 1996. Effects of growth hormone and insulin-like growth factor I on salinity tolerance and gill $\mathrm{Na}+, \mathrm{K}+$-ATPase in Atlantic salmon (Salmo salar): Interaction with cortisol. Gen Comp Endocr 101, 3-11.

McCormick SD, Cunjak RA, Dempson B, O'Dea MF, Carey JB. 1999. Temperature-related loss of smolt characteristics in Atlantic salmon (Salmo salar) in the wild. Can J Fish Aquat Sci 56, 1649-1657.

McCormick SD. 2001. Endocrine control of osmoregulation in teleost fish. American Zoologist 41, 781-794.

McCormick SD, O’Dea MF, Moeckel AM, Björnsson BT. 2003. Endocrine and physiological changes in Atlantic salmon smolts following hatchery release. Aquaculture 222, 45-57.

McCormick SD. 2009. Evolution of the hormonal control of animal performance: insights from the seaward migration of salmon. Integr Comp Biol 49, 408-422.

McCormick SD, Regish AM, Christensen AK. 2009. Distinct freshwater and seawater isoforms of $\mathrm{Na}+/ \mathrm{K}+$-ATPase in gill chloride cells of Atlantic salmon. J Exp Biol 212, 3994-4001.

McCormick SD, Sheehan TF, Björnsson BT, Lipsky C, Kocik JF, et al. 2013. Physiological and endocrine changes in Atlantic salmon smolts during hatchery rearing, downstream migration, and ocean entry. Can J Fish Aquat Sci 70, 105-118.

McCormick SD, Regish AM, Christensen AK, Bjornsson BT 2013. Differential regulation of sodium-potassium pump isoforms during smolt development and seawater exposure of Atlantic salmon. J Exp Biol 216, 1142-1151.

McCormick SD. 2013. Smolt physiology and endocrinology. In: Fish physiology: euryhaline fishes. $1^{\text {st }}$ ed. McCormick SD, Farrel AP, Brauner CJ (eds). Academic Press, Waltham, USA, Pp 199-251.

McKay I, Koltenyuk V, Lema S, McCormick S, Breves J. 2020. Intestinal gene expression of $\mathrm{Na}+\mathrm{HCO} 3$ - cotransporter 1 (Nbce1) isoforms in Atlantic salmon during smoltification and seawater acclimation. The FASEB Journal 34, 1.

McLeod C, Grice J, Campbell H, Herleth T. 2006. Super salmon: the industrialisation of fish farming and the drive towards GM technologies in salmon production. Discussion Paper $N^{\circ} 5$, CSAFE, University of Otago, Otago, Canada.

Melingen GO, Stefansson SO, Berg A, Wergeland HI. 1995. Changes in serum protein and IgM concentration during smolting and Early post-smolt period in vaccinated and unvaccinated Atlantic salmon (Salmo salar L.). Fish Shellfish Immunol 5, 211-221.

Moore LJ, Jarungsriapisit J, Nilsen TO, Stefansson S, Taranger GL, et al. 2017. Immune gene profiles in Atlantic salmon (Salmo salar L.) post-smolts infected with SAV3 by bath-challenge show a delayed response and lower levels of gene transcription compared to injected fish. Fish Shellfish Immun 62, 320-331.

Morgan JD, Sakamoto T, Grau EG, Iwama GK. 1997. Physiological and respiratory responses of the Mozambique tilapia (Oreochromis mossambicus) to salinity acclimation. Comp Biochem Phys A 117, 391-398.

Mowi. 2020. Salmon Farming Industry Handbook 2020. Mowi ASA, Bergem, Norway.

Muona M, SoivioA. 1992. Changes in plasma lysozyme and blood leucocyte levels of hatchery-reared Atlantic salmon (Salmo salar L.) and sea trout (Salmo trutta L.) during parr-smolt transformation. Aquaculture 106, 75-87.

Nemova NN, Nefedova ZA, Pekkoeva SN, Voronin VP, Shulgina NS, et al. 2020. The effect of the photoperiod on the fatty acid profile and weight in hatchery-reared underyearlings and yearlings of Atlantic salmon Salmo salar L. Biomolecules 10, 845.

Nilsen TO, Ebbesson LOE, Madsen SS, McCormick SD, Andersson E, et al. 2007. Differential expression of gill $\mathrm{Na}+, \mathrm{K}+-$ ATPase $\alpha$ - and $\beta$-subunits, $\mathrm{Na}+, \mathrm{K}+, 2 \mathrm{Cl}-$ cotransporter and CFTR anion channel in juvenile anadromous and landlocked Atlantic salmon Salmo salar. J Exp Biol 210, 2885-2896.

Nisembaum LG, Martin P, Fuentes M, Besseau L, Magnanou E, et al. 2020. Effects of a temperature rise on melatonin and thyroid hormones during smoltification of Atlantic salmon, Salmo salar. $J$ Comp Physiol B 190, 731-748.

Nuñez-Ortiz N, Moore LJ, Jarungsriapisit J, Nilsen TO, Stefansson S, et al. 2018. Atlantic salmon post-smolts adapted for a longer time to seawater develop an effective humoral and cellular immune response against salmonid alphavirus. Fish Shellfish Immunol 82, 579-590.

Olson TK, Criddle KR. 2008. Industrial evolution: a case study of Chilean salmon aquaculture. Aquacult Econ Manag 12, 89-106.

Pelis RM, Zydlewski JZ, McCormick SD. 2001. Gill Na(+)-K(+)-2Cl(-) cotransporter abundance and location in Atlantic salmon: effects of seawater and smolting. Am J Physiol-Reg I 280, R1844-R1852.

Pontigo JP, Agüero MJ, Sánchez P, Oyarzún R, Vargas-Lagos C, et al. 2016. Identification and expressional analysis of NLRC5 inflammasome gene in smolting Atlantic salmon (Salmo salar). Fish Shellfish Immun 58, 259-265.

van Rijn CA, Jones PL, Evans BS, Huynh C, McCormick SD, et al. 2020. Characterization of smoltification in the tasmanian strain of Atlantic salmon (Salmo salar) in recirculation and flow-through systems. Aquaculture 516, 734603.

van Rijn CA, Jones PL, Schultz AG, Evans BS, McCormick SD, et al. 2020. Atlantic salmon (Salmo salar) exposed to different preparatory photoperiods during smoltification show varying responses in gill $\mathrm{Na}+\mathrm{K}+-\mathrm{ATPase}$, salinity-specific MRNA transcription and ionocyte differentiation. Aquaculture 529, 735744.

Rohmann KN, Deitcher DL, Bass AH. 2009. Calcium-activated potassium (BK) channels are encoded by duplicate Slo1 genes in teleost fishes. Mol Biol Evol 26, 1509-1521.

Sakamoto T, McCormick SD. 2006. Prolactin and growth hormone in fish osmoregulation. Gen Comp Endocr 147, 24-30.

Seidelin M, Madsen SS, Blenstrup H, Tipsmark CK. 2000. Time-course changes in the expression of $\mathrm{Na}+, \mathrm{K}+$-ATPase in gills and pyloric caeca of Brown trout (Salmo trutta) during acclimation to seawater. Physiol Biochem Zool 73, 446-453.

SERNAPESCA, Servicio Nacional de Pesca. 2019. Informe sanitario de salmonicultura en centros marinos 1er semestre año 2019. Ministerio de Economía, Fomento y Turismo, Santiago, Chile.

Sharron S. 2015. Fish out of salt water: smoltification in subyearling chinook salmon from the laurentian great lakes. MSc Thesis, University of Western Ontario, Ontario, Canada.

Shwe A, Østbye TK, Krasnov A, Ramberg S, Andreassen R. 2020. Characterization of differentially expressed MiRNAs and their predicted target transcripts during smoltification and adaptation to seawater in head kidney of Atlantic salmon. Genes 11, 1059.

Staurnes M, Sigholt T, Asgard T, Baeverfjord G. 2001. Effects of a temperature shift on seawater challenge test performance in Atlantic salmon (Salmo salar) smolt. Aquaculture 201, 153-159.

Stefansson SO, Berge ÅI, Gunnarsson GS. 1998. Changes in seawater tolerance and gill $\mathrm{Na}+, \mathrm{K}+-\mathrm{ATPase}$ activity during desmoltification in Atlantic salmon kept in freshwater at different temperatures. Aquaculture 168, 271-277.

Stefansson SO, Björnsson BTh, Ebbesson LOE, McCormick SD. 2008. Smoltification. In: Fish Larval Physiology, 639-681.

Striberny A, Lauritzen DE, Fuentes J, Campinho MA, Gaetano P, et al. 2021. More than one way to smoltify a salmon? Effects of dietary and light treatment on smolt development and seawater growth performance in Atlantic salmon. Aquaculture 532, 736044.

Subpesca, Subsecretaria de Pesca y Agricultura. 2020. Informe Sectorial de Pesca y Acuicultura. Subpesca, Santiago, Chile.

Suzuki Y, Itakura M, Kashiwagi M, Nakamura N, Matsuki T, et al. 1999. Identification by differential display of a hypertonicity-inducible inward rectifier potassium channel highly expressed in chloride cells. J Biol Chem 274, 11376-11382.

Tipsmark CK, Sorensen KJ, Madsen SS. 2010. Aquaporin expression dynamics in osmoregulatory tissues of Atlantic salmon during smoltification and seawater acclimation. J Exp Biol 213, 368-379.

Tipsmark CK, Baltzegar DA, Ozden O, Grubb BJ, Borski RJ. 2008. Salinity regulates claudin MRNA and protein expression in the teleost gill. Am J Physiol-Reg I 294, R1004-R1014. 
Tipsmark CK, Madsen SS, Seidelin M, Christensen AS, Cutler CP. 2002. Dynamics of $\mathrm{Na}+\mathrm{K}+, 2 \mathrm{Cl}$ - cotransporter and $\mathrm{Na}+, \mathrm{K}+-\mathrm{ATPase}$ expression in the branchial epithelium of brown trout (Salmo trutta) and Atlantic salmon (Salmo salar). J Exp Zool 293, 106-118.

Vargas-Lagos C, Pontigo JP, Oyarzún R, Soto-Dávila M, Morera FJ, et al. 2018. Intestinal incomplete process on the osmoregulation system during Salmo salar smoltification in a productive conditions. Aquaculture 491.

Versen M, Mulugeta T, Blikeng BG, West AC, Jørgensen EH, et al. 2020. RNA profiling identifies novel, photoperiod-history dependent markers associated with enhanced saltwater performance in juvenile Atlantic salmon. PLOS ONE 15, e0227496.

Wang J, Kortner TM, Chikwati EM, Li Y, Jaramillo-Torres A, et al. 2020 Gut immune functions and health in Atlantic salmon (Salmo salar) from late freshwater stage until one year in seawater and effects of functional ingredients: a case study from a commercial sized research site in the Arctic region. Fish Shellfish Immunol 106, 1106-1119.

West CA, Mizoro Y, Wood SH, Ince L, Iversen M, et al. 2020. A single nuclei transcriptomic analysis of the Atlantic salmon gill through smoltification and seawater transfer. BioRxiv, January, 2020.09.03.281337.

Wu YC, Lin LY, Lee TH. 2003. Na+,K+,2CI--Cotransporter: a novel marker for identifying freshwater-and seawater-type mitochondria-rich cells in gills of the euryhaline tilapia, Oreochromis mossambicus. Zool Stud 42, 186-192.

Zaugg WS. 1982. A Simplified Preparation for adenosine triphosphatase determination in gill tissue. Can J Fish Aquat Sci 39, 215-217.

Zydlewski GB, Zydlewski J. 2012. Gill Na +,K +-ATPase of Atlantic salmon smolts in freshwater is not a predictor of long-term growth in seawater. Aquaculture 362-363, 121-126. 